PERM JOURNAL OF PETROLEUM AND MINING ENGINEERING ВЕСТНИК ПНИПУ. ГЕОЛОГИЯ. НЕФТЕТАЗОВОЕ И ГОРНОЕ ДЕЛО ISSN 2224-9923 Volume/ Tom 19 №2 2019

http://vestnik,pstu.ru/geo/

UDC 622.276:622.24.063-047.37

Article / Статья

(c) PNRPU / ПНИПУ, 2019

\title{
STUDIES OF HYDGOCARBON-BASED MUDS FOR DRILLING-IN PRODUCTIVE FORMATIONS
}

\author{
Mariya V. Nutskova, Dmitry A. Sidorov, Daniel E. Tsikplonu, Grigoriy M. Sergeev, Nikolay I. Vasiliev
}

Saint-Petersburg Mining University (2 21st Line, Vasilyevskiy island, Saint Petersburg, 199106, Russian Federation)

\section{ИССЛЕДОВАНИЯ БУРОВЫХ РАСТВОРОВ НА УГЛЕВОДОРОДНОЙ ОСНОВЕ ДЛЯ ПЕРВИЧНОГО ВСКРЫТИЯ ПРОДУКТИВНЫХ ПЛАСТОВ}

\author{
М.В. Нуцкова, Д.А. Сидоров, Д.Э. Тсикплону, Г.М. Сергеев, Н.И. Васильев \\ Санкт-Петербургский горный университет (199106, Россия, г. Санкт-Петербург, 21-я линия Васильевского острова, 2)
}

Received / Получена: 11.03.2019. Accepted / Принята: 01.06.2019. Published / Опубликована: 28.06.2019

Key words:

well drilling, flushing,

complications, laboratory studies,

rheology, plastic viscosity,

assumed viscosity, synthetic

asphalt, gilsonite, hydrocarbon-

based muds, emulsion muds,

structure formation, productive

formation, filtration, density.

\begin{abstract}
Purpose of the work is to increase effectiveness of drilling-in productive formations while using hydrocarbon-based muds. Several studies were performed within the work: evaluation of aqueous phase contents on alteration of rheological parameters of muds; evaluation of kind of gilsonite in hydrocarbon-based muds on its structure rheological and filtration properties.

Well completion using hydrocarbon-based muds is most efficient for purpose of preserving filtration and capacity properties of productive formation, but such muds are expensive enough. With purpose to reduce cost of such systems emulsion muds were developed, becoming more used during drilling-in, but for their efficient usage it is necessary to select components composition with reason, as even slight variations in quantity of reagents responsible for system stability, may lead to emulsion coalescence and phase separation.

Drilling-in productive formation using emulsion mud may lead to many complications, lessening reservoir to well connectivity or reducing reservoir permeability. One of such complications is loss of circulation. Mud used to drill-in formation should be made so that to practically avoid decline natural permeability of productive zones, provide for excellent hole cleaning and be easily conditioned.

Various materials exist, such as gilsonite (natural asphalt) or bitumen and amine-treated lignin, and also polymeric fillers used to prevent thieving due to reducing filtration and formation of impermeable mud cake.

Studies made within the work have demonstrated effectiveness of application of natural and synthetic asphalts in hydrocarbon-based muds, and also opened new directions for further studies with purpose to expose regularities appearing with change of components composition.
\end{abstract}

Целью работы является повышение эффективности вскрытия продуктивных пластов при использовании буровых растворов на углеводородной основе. В работе проведено несколько исследований: оценка влияния содержания водной фазы на изменение реологических параметров растворов; оценка влияния вида гильсонита в растворах на углеводородной основе на его структурно-реологические и фильтрационные параметры.

Заканчивание скважин с применением растворов на углеводородной основе наиболее целесообразно с целью сохранения фильтрационно-емкостных свойств продуктивного пласта, однако такие растворы достаточно дорогостоящие. С целью снижения стоимости таких систем были разработаны эмульсионные растворы, которые находят все большее применение при первичном вскрытии, но для эффективного их использования необходимо обоснованно проводить выбор компонентного состава, поскольку даже небольшие колебания количества реагентов, отвечающих за стабильность системы, могут приводить к коалесценции эмульсии и разделению фаз.

Вскрытие продуктивных пластов с эмульсионным раствором может привести к множеству осложнений, которые уменьшают связь коллектора со стволом скважины или уменьшают проницаемость пласта. Одним из таких осложнений является потеря циркуляции бурового раствора. Раствор, применяемый для вскрытия пласта, должен быть предназначен для того, чтобы практически не ухудшать естественную проницаемость продуктивных зон, обеспечивать превосходную промывку ствола и легко очищаться.

Существуют различные материалы, такие как гильсонит (природный асфальт) или битум и обработанный амином лигнин, а также полимерные наполнители, применяемые для профилактики поглощений за счет снижения фильтрации и образования непроницаемой фильтрационной корки.

Исследования, проведенные в работе, показали эффективность применения природных и синтетических асфальтов в растворах на углеводородной основе, а также открыли новые направления для дальнейших исследований с целью выявления закономерностей, возникающих при изменении компонентного состава.

\footnotetext{
Mariya V. Nutskova (Author ID in Scopus: 57191341737) - PhD in Engineering, Associate Professor at the Department of Well Drilling (tel.: +007 812 328 84 78, e-mail: Nutskova MV@pers.spmi.ru). The contact person for correspondence

Dmitry A. Sidorov - master student at the Department of Well Drilling (tel.: +007812 32884 78, e-mail: s172163@stud.spmi.ru).

Daniel E. Tsikeplonu - PhD student of the Department of Well Drilling (tel.: +007 81232884 78, e-mail: Tsikplonu_DE@pers.spmi.ru).

Grigoriy M. Sergeev (tel.: +007 98181883 39, e-mail: gosha sergeev12@mail.ru).

Nikolay I. Vasiliev (Author ID in Scopus: 57189715021) - Doctor of Technical Sciences, Professor at the Department of Well Drilling (tel.: +007 812 328 82 61, e-mail: Vasilev_NI@pers.spmi.ru).

Нуцкова Мария Владимировна - кандидат технических наук, доцент кафедры бурения скважин (тел.: +007 81232884 78, e-mail: Nutskova_MV@pers.spmi.ru). Контактное лицо для переписки.

Сидоров Дмитрий Андреевич - магистрант кафедры бурения скважин (тел.: +007 812328 84 78, e-mail: s172163@stud.spmi.ru).

Тсикплону Даниел Эдем - аспирант кафедры бурения скважин (тел.: +007 812328 84 78, e-mail: Tsikplonu_DE@pers.spmi.ru).

Сергеев Григорий Михайлович (тел.: +007 981818 83 39, e-mail: gosha sergeev12@mail.ru).

Васильев Николай Иванович - доктор технических наук, профессор кафедры бурения скважин (тел.: +007 812328 82 61, e-mail: Vasilev_NI@pers.spmi.ru)
} 


\section{Introduction}

World practice of well construction shows that further operation depends on effectiveness of drilling and well completion. Well drilling quality to great extent is determined not only by tools used, but also by technology, including washing processes inseparably related to type and quality of muds [1-11]. With purpose to maintain reservoir properties of near-wellbore formation zone at drilling-in productive horizon hydrodynamic pressure at well bottom should be kept at level of formation pressure or a bit lower, but in latter case probability of gas, oil and water inflows exists, to control which drilling site should be equipped with sealed circulation system, with rotating preventer installed at wellhead. While drilling with hydrodynamic pressure exceeding formation pressure, possibility of damage to formation nearwell zone increases, especially when using muds with insoluble micro-fine solids, which could penetrate deep into formation.

During well operation productive formation could restore its permeability due to cleaning nearwellbore zone, but this is applicable only to highly permeable reservoirs. During development of deposits with medium or low permeability this phenomenon is not observed when traditional methods are used. Consequently, in avoidance of damage to formation near-well zone the most important role will belong to selection of mud for drilling-in productive horizon, which would prevent possibility of deep penetration of its filtrate into formation at moment of overbalance appearance, especially at well cementing stage [12-20].

At present a number of muds is used for drilling-in productive formations with different permeability return coefficients $[14,15,18,21-25]$. The lowest coefficient value is with clay muds with weighting materials (for drilling in conditions of abnormally high formation pressure) - not more than $0,05-0,1$; for aluminate muds - 0,2-0,4; salt water based clayless polymer muds - for them the value is $0,2-0,4$. Permeability return coefficient for biopolymer muds is about 0,3-0,45; for aqueous muds with different mineralization - $0,45-0,85$; at foam drilling-in productive formations - about 0,5 . The highest values are with hydrocarbon-based muds (OBM). For them value of the coefficient is about $0,6-0,9$.

During evaluation of quality of muds of this or that type contacting with reservoir and used to drill- in productive horizons, attention should be paid to the following aspects [26]:

- presence of emulsified water phase in hydrocarbon-based mud and its mineralization degree (characterizing possible swelling of clay particles in intrapore space during its interaction with water phase of hydrophobic emulsion mud in case of phase inversion);

- correspondence of solid phase of mud to pore structure with purpose to minimize deep colmatation of productive formation;

- minimal filtrate invasion parameters of process fluids used for well completion.

Drilling-in at overbalance leads to the greatest damage of low permeable formations during drilling, especially when using water-based muds with microfine solids, that is why for medium permeable and low permeable reservoirs it is reasonable to use muds with low content of solids, foam systems and hydrogen-based muds [20, 27-32].

Except that, during drilling directional wells including those with horizontal tailing-in, and also during branching, there is a great issue of wellbore stability, bringing weight to drilling tool, and also reduction of rod friction $[1,2,33-36]$. One of means aiding in trouble-free drilling of inclined and horizontal sections - application of mud systems with minimal friction coefficient $[37,38]$. Meanwhile in this hydrocarbon-based muds are most effective.

\section{Materials for mixing hydrocarbon-based muds}

As dispersion medium for OBM may be used such nonpolar fluids as oil and petroleum products, synthetic hydrocarbons. Suitability of this or that material is evaluated both by its physical and chemical properties, and by process properties of OBM made on their base [29, 39-48].

While selecting hydrocarbon phase it is necessary to check its flash point first of all. According to Oil and Gas Industry Safety Regulations flash point of prepared hydrocarbon-based mud should by $50^{\circ} \mathrm{C}$ exceed maximal expected mud temperature at wellhead [49]. OBM flash point is significantly higher than that of initial hydrocarbon medium, but during its selection it is also necessary to consider fire safety during initial stage of its preparation. Serious attention should be paid also to hydrocarbons toxicity, and their vapors maximal permissible concentration at workplace should not exceed the established norm. 
Oil is the most available and cheap variant for OBM dispersion medium. At present oil is of limited use in gelled form as process fluid for different processes (killing, perforation) in shallow low temperature wells.

Diesel fuel - petroleum product having received the widest application as OBM hydrocarbon phase. Condition of colloid components of OBM, their association degree is determined by content of aromatic and paraffin hydrocarbons in dispersion medium. Though all diesel fuel brands have approximately same physical and chemical characteristics: resin amount is within $40-50 \mathrm{mg}$ per $100 \mathrm{~cm}^{3}$ of fuel; density $-0,83-0,85 \mathrm{~g} / \mathrm{cm}^{3}$; viscosity $-4,0-6,0 \mathrm{cPs}$, which permits to maintain developed OBM recipes in different regions.

Mineral oil are united into petroleum products with low content of aromatic hydrocarbons, being of greater environmental danger. Positive quality of mineral oils is their best withdrawal from surface of drilled rock particles (residual quantity 5-6\% against $16-17 \%$ for diesel fuel).

Synthetic hydrocarbons - new generation dispersion medium for low toxic non-water based muds, being an ecological alternative to OBM, permitting to implement their advantages in regions with increased environment protection requirements.

Organophilic clays form as result of modification of clay materials by ammonium organic salts and find wide usage as effective additives to oils, paints and lubricants, as active fillers for plastics and rubbers, and also for preparing OBM.

Highly oxidized asphalt - product of oil tars air oxidation. Advantage of tar as structure-forming agent is that being organophilic naturally it does not require processing with wetting and hydrophobisating agents.

Water phase is main component of hydrophobic emulsion muds (HEM) determining their viscosity, structural and filtration properties. Not less important for HEM properties is also qualitative composition of water phase.

Fine dispersion fillers are intended mainly to stabilize suspension and emulsion OBM and to control filtration.

Calcium oxide - quicklime received during burning low shake limestones. It is used in majority of OBM recipes as source product to obtain active filler $\mathrm{Ca}(\mathrm{OH})_{2}$, forming at calcium oxide reaction with water.

Calcium carbonate (chalk, marble chips, calcite) is used as active filler and to weight OBM to density
$1,22-1,24 \mathrm{~g} / \mathrm{cm}^{3}$. Dry finely dispersed calcium carbonate is a good adsorbent of superficially active substances (SAS) and hydrophobizing components of hydrocarbon medium, it obtains oleophilic properties providing for its function as stabilizer and filtration reducer. Calcium carbonate is used in number of HEM recipes during drilling-in, completion of productive formations and well killing to increase permeability return coefficient in near-wellbore zone.

For OBM weighting in general same materials are used as those in aqueous systems: barite weighting materials (density $4,3-4,7 \mathrm{~g} / \mathrm{cm}^{3}$ ), carbonate weighting materials (limestone $-2,7 \mathrm{~g} / \mathrm{cm}^{3}$; dolomite $-2,8-2,9$ $\mathrm{g} / \mathrm{cm}^{3}$; siderite $\left.-3,8-3,9 \mathrm{~g} / \mathrm{cm}^{3}\right)$. To increase mud density in range of productive horizons application of carbonate weighting materials is appropriate, as they are acid-soluble, so harmful influence of productive formation colmatation by mud solid phase could be partially eliminated by acid treatments.

To achieve different process tasks OBM may contain various special fillers exerting substantial influence on their process properties. To such additives belong materials for OBM density reduction and mud loss prevention.

Usage of OBM in drilling-in highly permeable strongly drained fractured productive formations or killing wells in similar conditions with abnormally low formation pressures may lead to mud loss. It is not possible to obtain quality OBM with density lower than $0,86-0,87 \mathrm{~g} / \mathrm{cm}^{3}$ without usage of special lighting additives. Increase of lighting additives quantity leads to increase of OBM viscosity and structural parameters $[27,47,48]$.

To superficially active substances relate those organic compounds molecule of which simultaneously contain polar group and nonpolar hydrocarbon chain. SAS play huge role in OBM composition. Even small additions of special agents $(0,25-0,50 \%)$ are able fully change OBM properties. It is SAS complex being used in OBM recipes that determine mud aggregative and sedimentative stability, stability against action of aggressive factors, controls mud disperse phase solvation processes.

In composition of OBM SAS perform the following functions [39, 41, 42, 44, 46]:

- Emulsifiers (main and additional). These are oil soluble metallic soaps of organic acids, oil soluble ethoxylated derivatives from organic acids, compound ethers, amines, amides, imidazolines, oligomeric polyamides, compound ethers of fatty acids, amino alcohols, and so on. 
- Structure-forming agents. To this group of SAS relate compounds able to intensify coagulative structure forming when introduced into stable invert emulsion of the following substances: water soluble ethoxylated alkyl phenols type OP-10 and neonol 690, disolvan-4411, sulfonol NP-3 and other.

- Hydrophobisating agents. These SAS increase degree of affinity of OBM disperse phase to hydrocarbon disperse medium, protecting it against hydrophilic flocculation. In HEM composition these SAS often add to action of main emulsifiers, playing role of emulsion stabilizers.

- Viscosity reducers. They, due to adsorptive blocking of disperse phase particles, permit to substantially increase volumetric filling of its system not hindering process properties.

\section{Study of properties of hydrocarbon-based muds}

Hydrocarbon-based muds used in drilling majority of wells, are expensive systems, as a rule made abroad. In this work studies were performed using home-made agents with purpose to evaluate influence of component composition on process properties of muds prepared. Experimental studies were performed in laboratories of well drilling chair of National Mineral Resources University (University of Mines). Following agents are included into mud component composition:

- mineral oil - dispersion medium;

- SAS-emulsifier, hydrophobizing agent for solid phase surface, providing for interboundary tension reduction at border «oil - water», also acting as a coagulative structure forming agent. In capacity of hydrophobizing agent it improves temperature and rheological stability of emulsion [44];

- calcium oxide - to regulate alkalinity and as source of calcium to neutralize carbon dioxide and hydrogen sulfide;

- SAS-wetter - to increase coagulative structure forming when added to hydrocarbon-based muds [44];

- organophilic bentonite - for structure forming and to provide for necessary viscosity, high thermal stability, electrical stability, and also to reduce filtrate formation;

- calcium barite and carbonate with different fractional composition барит in capacity of colmatant and weighting agent;

- calcium chloride - to increase hole wall stability in clay sediments;

- gilsonite - as filtration reducer.
Table 1

Basic components composition

\begin{tabular}{|c|c|c|}
\hline Agent & Purpose in mud & $\begin{array}{c}\text { Rate, } \mathrm{g}\left(\mathrm{ml}^{*}\right) / 1 \\
\text { of mud }\end{array}$ \\
\hline Mineral oil & Mineral oil & $700^{*}$ \\
\hline $\mathrm{CaO}$ & Neutralizer $\mathrm{CO}_{2}, \mathrm{CO}_{3}$ & 35 \\
\hline Water & Water phase & $583^{*}$ \\
\hline $\mathrm{CaCl}_{2}$ & Inhibitor & 82 \\
\hline SAS-emulsifier & $\begin{array}{c}\text { Emulsifier, } \\
\text { hydrophobizing agent }\end{array}$ & 29 \\
\hline SAS-wetter & Wetter, structure forming agent & 12 \\
\hline Gilsonite & Water loss reducer & 6 \\
\hline Barite & Weighter & 350 \\
\hline CaCO & Colmatant & 117 \\
\hline Bentonite & Structure forming agent & 12 \\
\hline
\end{tabular}

Mud recipe taken as basic during studies is given in table 1.

To evaluate influence of hydrocarbons/water ratio on mud process properties seven muds were studied, having hydrocarbons/water ratio from 55/45 to $85 / 15$. Muds were prepared at laboratory mixer HamiltonBeach at mixing speed $12000-14000$ rev/min. Temperature of rheological parameters measurement $-50 \pm 2{ }^{\circ} \mathrm{C}$. Results of laboratory measurements of mud properties are given in table 2 .

Analysis of results of laboratory studies showed that along with reduction of water quantity assigned viscosity, plastic viscosity, dynamic shear stress, static shear stress increase to certain value being demonstrated by an evident maximum (hydrocarbons/water ratio $=70 / 30$ ), along with further ratio growth reduction of these parameters is observed. This may be explained by chemical nature of muds obtained - it is supposed that at great amount of water (ratios from 55/45 to 65/35) it is possible to note lack of SAS for free water emulsifying and wetting solid phase; with reduction of water amount (to ratio 70/30) at constant amount of other components the system comes to the optimum condition - emulsion is stabilized due to activity of SAS in quantity enough both for retaining solids in suspended state and for preserving emulsion. Further water amount reduction leads to reduction of rheological characteristics of the system, as main influence on rheology is made by hydrocarbon medium, being less and less «thickened» by water. Except that, same tendency is observed with mud density, but this may be related to air intake during mixing. Nevertheless, to obtain decisive confirmation of the hypothesis it is necessary to perform additional rheological studies aimed to evaluate influence of hydrocarbons/water ratio on system properties with other components. 


\section{Experimental studies of influence of asphalt application in capacity of filtration reducer in OBM}

To evaluate influence of kind of asphalt (appearance shown in fig. 1) on process characteristics of OBM basic mud was studied with kinds of asphalt:

Mud 1. TDM, natural asphalt.

Mud 2. Synthetic asphalt grade B (Synasphalt B).

Mud 3. Synthetis asphalt (Synasphalt).

Mud 4. Sulfonated asphalt.

Mud 5. Basic mud without asphalt.

This work gives results of laboratory studies (fig. 2) of rheological properties of hydrocarbonbased muds, measurements of rheological parameters were performed before heating (at temperature $25{ }^{\circ} \mathrm{C}$ ) and after heating to $90{ }^{\circ} \mathrm{C}$ (synthetic asphalts melting point $-80-85^{\circ} \mathrm{C}$ ).

Input of gilsonite leads to increase of assigned and plastic viscosity, but after heating these nuds to $90{ }^{\circ} \mathrm{C}$ natural asphalts (natural and sulfonated) increase mud assigned viscosity (comparing to basic mud) as they start to create structure, and synthetis asphalts (synasphalt and synasphalt grade B) demonstrate viscosity reduction due to their melting.

Input of gilsonite leads to reduction in dynamic sheer stress. Meanwhile after heating to $90{ }^{\circ} \mathrm{C}$ in mud with natural asphalt grade TDM increase of dynamic sheer is observed comparing to tests at room temperature.

Input of asphalt does not make significant influence on static sheer stress.

Input of asphalt without heating leads to increase of filtrate volume, but after heating these muds to 90 ${ }^{\circ} \mathrm{C}$ filtrate volume reduces significantly, as physical connection with permeable rocks is formed, creating effective cake to prevent penetration of mud and its filtrate into formation.

Speed of filtrate formation often is the most important property of mud, especially when drilling permeable formations, where hydrostatic pressure exceeds formation pressure. Correct filtration control may prevent or minimize drill pipe sticking, and improve wellbore stability in certain intervals. As a rule, large filtrate volumes are related to thick filter cake, as cake is made by sedimentation of clay particles on wellbore walls during loss of filtrate into formation. So, the greater is filtrate volume, the thicker is filter cake and mud is less effective. Studies showed that at high temperatures and pressures OBM without asphalt have highest mud spurt comparing to other compositions. In general the studies performed have demonstrated that usage of synthetic asphalt as water loss reducer is worthwhile.

Table 2

Mud parameters obtained

\begin{tabular}{|l|c|c|c|c|c|c|c|}
\hline \multirow{2}{*}{\multicolumn{1}{c|}{ Parameter measured }} & \multicolumn{9}{c|}{ Mud serial number } \\
\cline { 2 - 8 } & 1 & 2 & 3 & 4 & 5 & 6 & 7 \\
\hline Hydrocarbons/water, \% & $55 / 45$ & $60 / 40$ & $65 / 35$ & $70 / 30$ & $75 / 25$ & $80 / 20$ & $85 / 15$ \\
\hline Assigned viscosity, sec & 33,2 & 40 & 80 & 370 & 216 & 152 & 120 \\
\hline Plastic viscosity, $\mathrm{mPa} \cdot \mathrm{sec}$ & 21 & 33,5 & 63 & 68 & 63 & 61,5 & 48,5 \\
\hline Dynamic shear stress, $\mathrm{Pa}$ & 5 & 6,5 & 9,5 & 29 & 29 & 24,5 & 20,5 \\
\hline Static shear stress $10 \mathrm{sec}, \mathrm{Pa}$ & 4 & 4 & 8 & 18 & 18 & 12 & 9 \\
\hline Static shear stress $10 \mathrm{~min}, \mathrm{~Pa}$ & 4 & 4,5 & 7 & 17 & 18 & 13 & 10 \\
\hline Actual density, $\mathrm{g} / \mathrm{cm}^{3}$ & 1,17 & 1,22 & 1,25 & 1,28 & 1,27 & 1,29 & 1,29 \\
\hline Calculated density, $\mathrm{g} / \mathrm{cm}^{3}$ & 1,22 & 1,24 & 1,26 & 1,28 & 1,28 & 1,3 & 1,32 \\
\hline
\end{tabular}

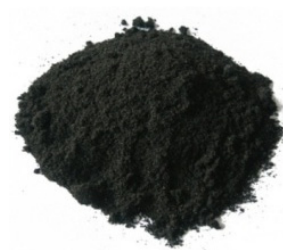

Natural asphalt TDM

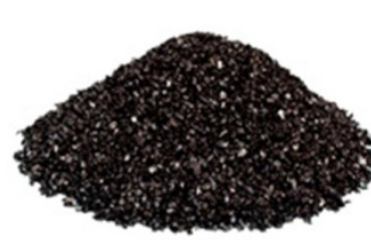

Synasphalt

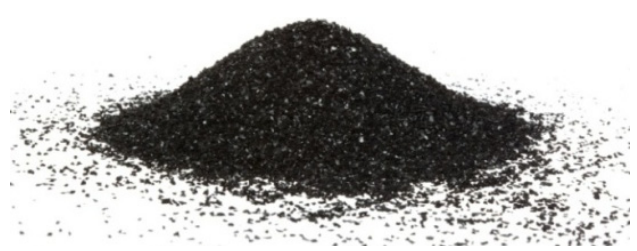

Synasphalt grade B

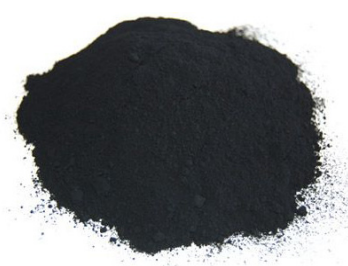

Sulfonated asphalt

Fig. 1. Appearance of studied asphalts 

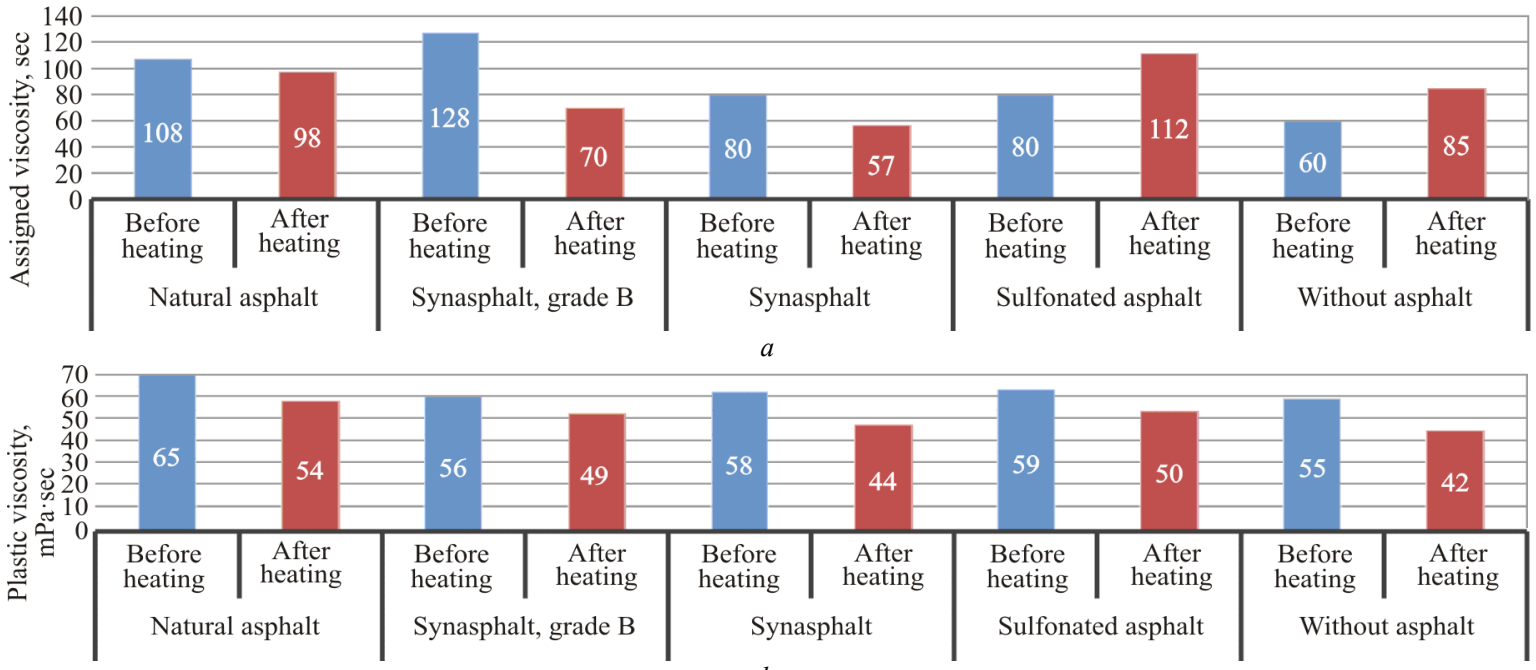

$b$
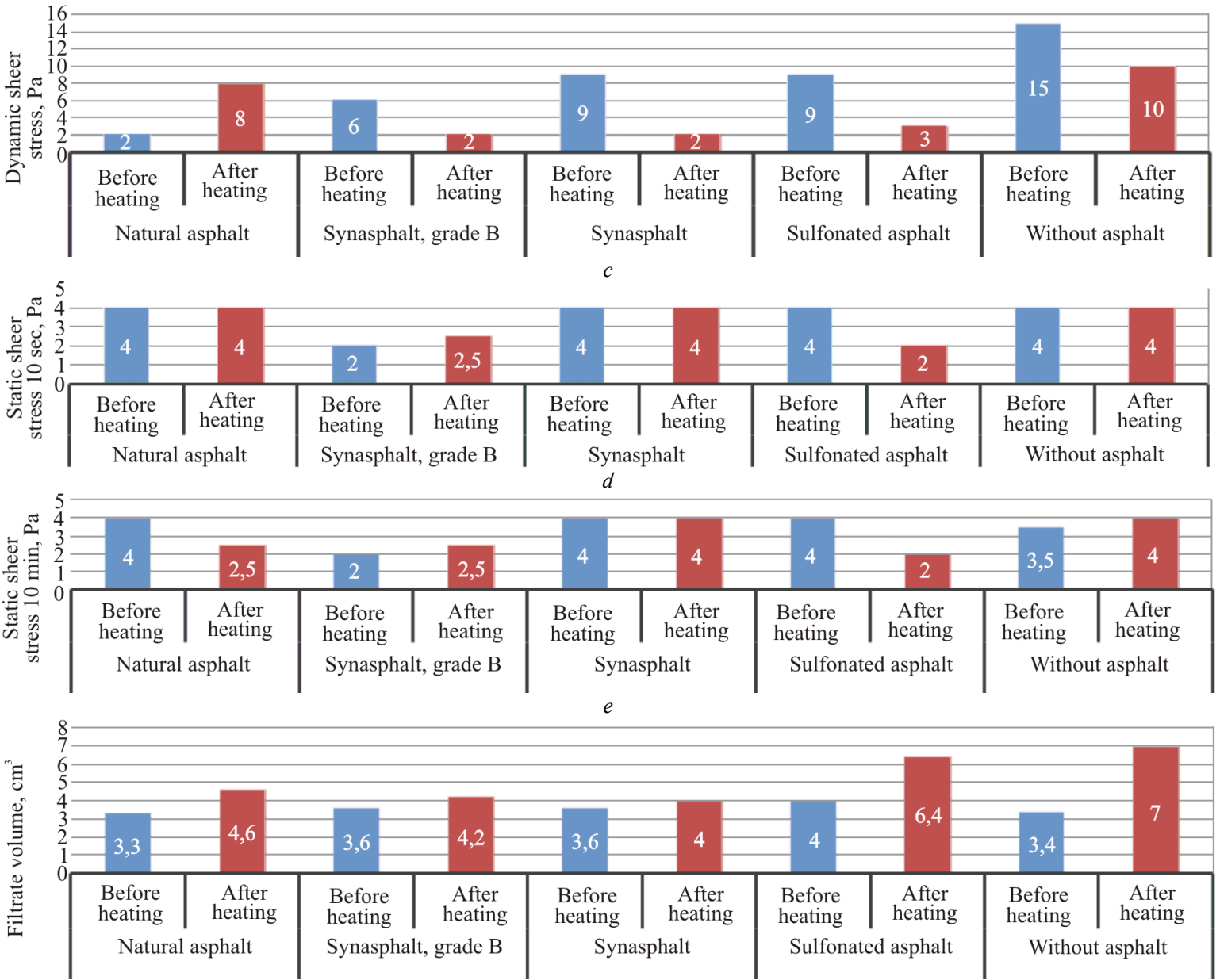

$f$

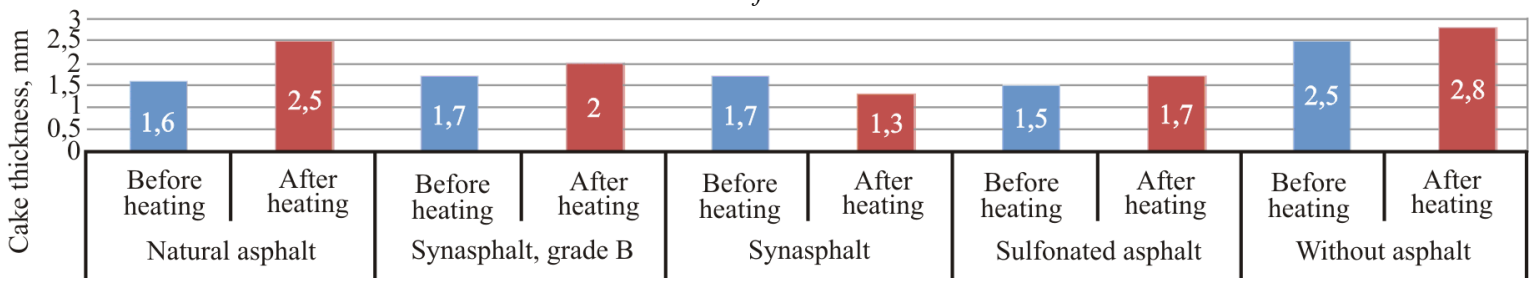

Fig. 2. Influence of kind of asphalt on: $a$ - assigned viscosity; $b$-plastic viscosity;

$c$-dynamic sheer stress; $d$ - static sheer stress $10 \mathrm{sec} ; e$ - static sheer stress $10 \mathrm{~min}$;

$f$ - filtrate volume; $g$ - thickness of hydrocarbon-based mud cake thickness 


\section{Conclusions}

Analysis of results of laboratory studies permitted to establish that hydrocarbons/water ratio exerts considerable influence on process properties of OBM, but in order to obtain regularities according to which it is possible to make an unambiguous decision on components composition, it is reasonably to perform a significant complex of experimental studies with different reagents.

Mud losses into formation while drilling with OBM happen in cavernous rocks and natural or artificial fractures in permeable and low permeable horizons. But this problem may be solved using such materials as asphalt, including synthetic, not widely used in drilling at present.

\section{References}

1. Dvoinikov M.V. Issledovaniia tekhnikotekhnologicheskikh parametrov bureniia naklonnykh skvazhin [Research on technical and technological parameters of inclined drilling]. Zapiski Gornogo instituta, 2017, vol.223, pp.86-92. DOI: $10.18454 /$ pmi.2017.1.86

2. Kozhevnikov E.V., Nikolaev N.I., Ozhgibesov O.A., Dvoretskas R.V. Issledovanie vliianiia sedimentatsii tamponazhnogo rastvora na svoistva poluchaemogo tsementnogo kamnia [Studying of sedimentation influencing on cement stone properties]. Oil industry, 2014, no.6, pp.23-25.

3. Nikolaev N.I., Leusheva E.L. Povyshenie effektivnosti bureniia tverdykh gornykh porod [Increasing of hard rocks drilling efficiency]. Oil industry, 2016, no.3, pp.68-71.

4. Oshibkov A.V., Vodorezov D.D., Syzrantseva K.V., Frolov S.A., Dvoinikov M.V., Bakirov D.L. Vliianie tekhnicheskikh kharakteristik klina-otklonitelia i obsadnykh trub na nadezhnost soedineniia stvolov mnogostvolnykh skvazhin [Influence of sidetracking characteristics on multilateral well construction reliability]. Oil industry, 2015, no.11, pp.121-123.

5. Dvoynikov M., Syzrantsev V., Syzrantseva K. Designing a high resistant, high-torque downhole drilling motor. International Journal of Engineering, Transactions A: Basics, 2017, 30(10), pp.1615-1621. DOI: 10.5829/ije.2017.30.10a.24

6. Dvoynikov M.V., Blinov P.A. Analysis of incident causes while directional and horizontal wells drilling. International Journal of Applied Engineering Research, 2016, 11(20), pp.10039-10042.

7. Dvoynikov M.V., Blinov P.A. Survey results of series-produced downhole drilling motors and technical solutions in motor design improvement. International Journal of Applied Engineering Research, 2016, 11(10), pp.7034-7039.

8. Kupavikh K.S., Nutskova M.V. Ecological features of oil well repair at low-permeability reservoir.
International Journal of Applied Engineering Research, 2016, 11(11), pp.7505-7508.

9. Moradi S.S.T., Ghasemi M.F., Nikolaev N.I., Lykov Y.V. Effect of fault stress regime on the mechanical stability of horizontal boreholes. GeoBaikal 2016 - 4th International Conference: From East Siberia to the Pacific - Geology, Exploration and Development, 2016. DOI: 10.3997/2214-4609.201601704

10. Moradi S.S.T., Nikolaev N.I., Chudinova I.V., Martel A.S. Geomechanical study of well stability in high-pressure, high-temperature conditions. Geomechanics and Engineering, 2018, 16(3), pp.331-339. DOI: 10.12989/gae.2018.16.3.331

11. TabatabaeeMoradi S.S., Nikolaev N.I. Considerations of cementing directional wells in highpressure, high-temperature conditions. 7th EAGE Saint Petersburg International Conference and Exhibition: Understanding the Harmony of the Earth's Resources Through Integration of Geosciences, 2016, pp.11-15. DOI: $10.3997 / 2214-4609.201600227$

12. Litvinenko V.S., Nikolaev N.I. Tekhnologicheskie zhidkosti dlia povysheniia effektivnosti stroitelstva i ekspluatatsii neftianykh i gazovykh skvazhin [Technological fluids for increasing effectivity of construction and exploitation oil and gas wells]. Zapiski Gornogo instituta, 2011, vol.194, pp.84-90.

13. Nikolaev N.I., Leusheva E.L. Razrabotka sostavov promyvochnykh zhidkostei dlia povysheniia effektivnosti bureniia tverdykh gornykh porod [Development of drilling fluids composition for efficiency increase of hard rocks drilling]. Zapiski Gornogo instituta, 2016, vol.219, pp.412-420. DOI: $10.18454 /$ pmi.2016.3.412

14. Turitsyna M.V., Kovalev A.V., Morozov V.A., Teleev G.Iu., Chernobrovin E.V., Shcherbakov A.A. gazozhidkostnye promyvochnye smesi dlia pervichnogo vskrytiia plastov $\mathrm{v}$ usloviiakh anomalno nizkikh plastovykh davlenii [Gas-liquid washover 
mixtures for the primary opening of productive layers in conditions of abnormally low reservoir pressure]. Oil industry, 2012, no.9, pp.58-59.

15. Turitsyna M.V., Chernobrovin E.V., Morozov V.A., Teleev G.Iu., Kovalev A.V., Riabokon E.P. Gazozhidkostnye promyvochnye smesi dlia zakanchivaniia skvazhin $\mathrm{v}$ usloviiakh anomalno nizkikh plastovykh davlenii [Gas-liquid washover mixtures for well completion in conditions of abnormally low formation pressure]. Oil industry, 2012, no.8, pp.111-113.

16. Blinov P.A., Dvoynikov M.V. The process of hardening loose rock by Mud Filtrat. International Journal of Applied Engineering Research, 2016, 11(9), pp.6630-6632.

17. Leusheva E., Morenov V. Research of clayless drilling fluid influence on the rocks destruction efficiency. International Journal of Applied Engineering Research, 2017, 12(6), pp.945-949.

18. Morenov V., Leusheva E., Martel A. Investigation of the fractional composition effect of the carbonate weighting agents on the rheology of the clayless drilling mud. International Journal of Engineering, Transactions A: Basics, 2018, 31(7), pp.1152-1158. DOI: 10.5829/ije.2018.31.07a.21

19. Nutskova M.V., Dvoynikov M.V., Kuchin V.N. Improving the quality of well completion in order to limit water inflows. Journal of Engineering and Applied Sciences, 2017, 12(22), pp. 5985-5989. DOI: $10.3923 /$ jeasci.2017.5985.5989

20. Nutskova M.V., Kupavyh K.S. Improving the quality of well completion in deposits with abnormally low formation pressure. International Journal of Applied Engineering Research, 2016, 11(11), pp. 7298-7300.

21. Vafin R. Improvement quality of opening the productive layers by complex usage of polysaccharides. Perm Journal of Petroleum and Mining Engineering, 2011, vol.10, no.1, pp.47-52.

22. Kurbanov Kh.N. Burovye rastvory dlia sokhraneniia filtratsionno-emkostnykh svoistv kollektora pri pervichnom vskrytii plasta [Drilling fluids to preserve the permeability and porosity of the collector in primary opening of the reservoir]. Inzhenerneftianik, 2016, no.3, pp.18-22.

23. Blinov P.A., Dvoynikov M.V. Rheological and filtration parameters of the polymer salt drilling fluids based on xanthan gum. Journal of Engineering and Applied Sciences, 2018, 13(14), pp.5661-5664. DOI: 10.3923/jeasci.2018.5661.5664

24. Blinov P.A., Podoliak A.V. The method of determining the effects of drilling fluid on the stability of loose rocks. International Journal of Applied Engineering Research, 2016, 11(9), pp.6627-6629.

25. Morenov V., Leusheva E. Development of drilling mud solution for drilling in hard rocks. International Journal of Engineering, Transactions A: Basics, 2017, 30(4), pp.620-626.

26. Avetisov A.G., Bondarev V.I., Bulatov A.I., Sukurenko E.I. Optimizatsiia protsessov promyvki i krepleniia skvazhin [Optimization of well washing and fixing process]. Moscow, Nedra, 1980, $221 \mathrm{p}$.

27. Garshina O.V., Khvoshchin P.A., Kuznetsova O.G., Kudimov I.A., Okromelidze G.V. Razrabotka, opyt primeneniia i perspektivy povtornogo ispolzovaniia invertno-emulsionnykh burovykh rastvorov [Development, application of invert emulsion drilling fluids and prospects of their reuse]. Oil industry, 2011, no.10, pp.56-59.

28. Konesev V.G., Khomutov A.Iu. Rezultaty primeneniia rastvorov na uglevodorodnoi osnove pri vskrytii produktivnykh plastov na mestorozhdeniiakh oao "Gazpromneft - Noiabrskneftegaz" [Application of oil-based drilling muds in reservoir rocks of Gazpromneft-Noyabrskneftegas JSC fields]. Oil industry, 2016, no.5, pp.44-45.

29. Nekrasova I.L. Improvement of the criteria for assessing the quality of hydrocarbon-based muds in terms of geological conditions of their use. Perm Journal of Petroleum and Mining Engineering, 2018, vol.18, no.2, pp.129-139. DOI: $10.15593 / 2224-9923 / 2018.4 .3$

30. Iakovlev A.A., Turitsyna M.V. Issledovanie svoistv gazozhidkostnykh smesei i vybor ikh ratsionalnykh sostavov dlia pervichnogo vskrytiia plastov s anomalno nizkimi davleniiami [Investigation of the properties of gas-liquid mixtures and the choice of their rational compositions for the initial opening of layers with abnormally low pressures]. Inzhenerneftianik, 2012, no.2, pp.27-31.

31. Iakovlev A.A., Turitsina M.V. Foundation the application and investigation of liquid-gas mixtures compositions for flushing-out borehole cavities in conditions of anomalous low formation pressure. Perm Journal of Petroleum and Mining Engineering, 2012. vol.11, no.4, pp.42-48.

32. Iakovlev A.A., Turitsyna M.V. Obosnovanie sposoba i vybor promyvochnogo agenta dlia pervichnogo vskrytiia plastov $\mathrm{s}$ anomalno nizkim davleniem [Justification of the way and choice of the mud fluid for primary opening-out of layers with 
abnormally low pressure]. Zapiski Gornogo instituta, 2013, vol.206, pp.116-119.

33. Bakirov D.L., Babushkin E.V., Fattakhov M.M., Maliutin D.V. Povyshenie effektivnosti bureniia mnogozaboinykh skvazhin za schet primeneniia rastvorov na uglevodorodnoi osnove [Improving the efficiency of multilateral wells construction by the use of oil-based drilling fluids]. Oil industry, 2016, no.8, pp.28-30.

34. Bakirov D.L., Podkuiko P.P., Babushkin E.V., Fattakhov M.M., Akhmetshin I.K. Rezultaty ispytaniia burovykh rastvorov na uglevodorodnoi osnove pri zarezke bokovykh stvolov na Nong-Eganskom mestorozhdenii [Results of oil based drilling mud testing when sidetracking in the Nong-Eganskoye oil field]. Oil industry, 2012, no.11, pp.108-109.

35. Bulatov A.I., Provelkov E.Iu., Proselkov Iu.M. Burenie gorizontalnykh skvazhin [Horizontal well drilling]. Krasnodar, Sovetskaia Kuban, 2008, 424 p.

36. Kozhevnikov E.V., Nikolaev N.I., Melekhin A.A., Turbakov M.S. Issledovanie svoistv tamponazhnykh rastvorov dlia krepleniia neftianykh skvazhin $\mathrm{s}$ protiazhennym gorizontalnym uchastkom, proburennykh $\mathrm{s}$ ispolzovaniem rotornykh upravliaemykh sistem [Studying the properties of cement slurries for cementing oil wells with long horizontal section drilled with rotary steerable systems]. Oil industry, 2015, no.9, pp.58-60.

37. Melekhin A.A., Chernyshov S.E., Blinov P.A., Nutskova M.V. Issledovanie smazyvaiushchikh dobavok $\mathrm{k}$ burovym rastvoram dlia snizheniia koeffitsienta treniia pri stroitelstve skvazhin rotornymi upravliaemymi sistem [Study of lubricant additives to the drilling fluid for reducing the friction coefficient during well construction with rotary steerable system]. Oil industry, 2016, no. 10, pp.52-55.

38. Blinov P.A., Dvoynikov M.V., Sergeevich K.M., Rustamovna A.E. Influence of mud filtrate on the stress distribution in the row zone of the well. International Journal of Applied Engineering Research, 2017, 12(15), pp.5214-5217.

39. Agabaliants E.G. Promyvochnye zhidkosti dlia oslozhnennykh uslovii bureniia [Wash fluids for complicated drilling conditions]. Moscow, Nedra, 1982, $184 \mathrm{p}$.

40. Basarygin Iu.M., Bulatov A.I., Proselkov Iu.M. Oslozhneniia $\mathrm{i}$ avarii pri burenii neftianykh i gazovykh skvazhin [Complications and accidents while drilling oil and gas wells]. Moscow, Nedra, $2000,680 \mathrm{p}$.
41. Gorodnov V.D. Burovye rastvory [Drilling fluids]. Moscow, Nedra, 1985, $131 \mathrm{p}$.

42. Dukhon P.Iu., Dolgikh A.E., Sherman G.P. Metody kontrolia sostava i svoistv rastvora na uglevodorodnoi osnove [Methods for controlling the composition and properties of hydrocarbon-based solution]. Trudy Instituta geologii $i$ razrabotki goriuchikh iskopaemykh AN SSSR, 1976, iss.27.

43. Kravchuk M.V. Vybor burovogo rastvora pri vskrytii terrigennykh otlozhenii na mestorozhdeniiakh Timano-Pechorskoi provintsii [The choice of drilling fluid at the opening of terrigenous deposits in the fields of the Timan-Pechora province]. Stroitelstvo neftianykh i gazovykh skvazhin na sushe i na more, 2015, no.1-2.

44. Mukhin L.K. Burovye rastvory na uglevodorodnoi osnove dlia bureniia $\mathrm{v}$ oslozhnennykh usloviiakh i vskrytiia produktivnykh plastov [Hydrocarbon-based drilling fluids for drilling in difficult conditions and production reservoir breakdown]. Doctor's degree dissertation. Moscow, 1971, $300 \mathrm{p}$.

45. Mukhin L.K., Zavorotnyi Vl., Travnikova L.A., Ropianaia M.A., Efimov N.I., Kasperskii B.V., Shishkov S.N. Ekologicheskie aspekty primeneniia burovykh rastvorov na uglevodorodnoi osnove [Environmental aspects of the use of hydrocarbonbased drilling fluids]. Problemy stroitelstva neftianykh $i$ gazovykh skvazhin. Tezisy dokladov $k$ vsesoiuznoi konferentsii. Krasnodar, 1990.

46. Orlov G.A., Kendis M.Sh., Glushchenko V.N. Primenenie obratnykh emulsii $\mathrm{V}$ neftedobyche [The use of inverse emulsions in oil production]. Moscow, Nedra, 1991, 225 p.

47. Ianovskii V.A., Andropov M.O., Churkin R.A., Fakhrislamova R.S., Fenzel A.D., Minaev K.M. Vliianie khimicheskoi prirody emulgatorov riada proizvodnykh zhirnykh kislot i etanolaminov na svoistva gidrofobno-emulsionnykh burovykh rastvorov [The effect of the chemical nature of emulsifiers of some fatty acid derivatives and ethanolamines on the oil-based drilling fluids properties]. Oil industry, 2018, no.1, pp.42-47.

48. Ianovskii V.A., Fenzel A.D., Andropov M.O., Fakhrislamova R.S., Zakharov A.S., Churkin R.A., Minaev K.M. Vliianie uslovii sinteza emulgatora na svoistva gidrofobno-emulsionnogo burovogo rastvora [The effect of synthesis conditions of emulsifier on the properties of oil-based drilling muds]. Oil industry, 2018, no.6, pp.93-97. DOI: $10.24887 / 0028-2448-2018-6-93-97$ 
49. Ob utverzhdenii federalnykh norm i pravil $\mathrm{v}$ oblasti promyshlennoi bezopasnosti "Pravila bezopasnosti v neftianoi i gazovoi promyshlennosti": Prikaz ot 12 marta 2013 g. № 101 [On approval of federal rules and regulations in the field of industrial safety "Safety rules in the oil and gas industry": Order of March 12, 2013 No. 101], available at: http://www.ptb72.ru/upload/Prikaz_RTN_ot_12.03 .13_101.pdf (accessed 16 February 2019).

\section{Библиографический список}

1. Двойников М.В. Исследования техникотехнологических параметров бурения наклонных скважин // Записки Горного института. - 2017. T. 223. - C. 86-92. DOI: 10.18454/pmi.2017.1.86

2. Исследование влияния седиментации тампонажного раствора на свойства получаемого цементного камня / Е.В. Кожевников, Н.И. Николаев, О.А. Ожгибесов, Р.В. Дворецкас // Нефтяное хозяйство. -2014 . - № 6. - С. 23-25.

3. Николаев Н.И., Леушева Е.Л. Повышение эффективности бурения твердых горных пород // Нефтяное хозяйство. - 2016. - № 3. - С. 68-71.

4. Влияние технических характеристик клинаотклонителя и обсадных труб на надежность соединения стволов многоствольных скважин / А.В. Ошибков, Д.Д. Водорезов, К.В. Сызранцева, С.А. Фролов, М.В. Двойников, Д.Л. Бакиров // Нефтяное хозяйство. - 2015. - № 11. - С. 121-123.

5. Dvoynikov M., Syzrantsev V., Syzrantseva K. Designing a high resistant, high-torque downhole drilling motor // International Journal of Engineering, Transactions A: Basics. - 2017. - 30 (10). P. 1615-1621. DOI: 10.5829/ije.2017.30.10a.24

6. Dvoynikov M.V., Blinov P.A. Analysis of incident causes while directional and horizontal wells drilling // International Journal of Applied Engineering Research. - 2016. - 11 (20). P. 10039-10042.

7. Dvoynikov M.V., Blinov P.A. Survey results of series-produced downhole drilling motors and technical solutions in motor design improvement // International Journal of Applied Engineering Research. - 2016. - 11 (10). - P. 7034-7039.

8. Kupavikh K.S., Nutskova M.V. Ecological features of oil well repair at low-permeability reservoir // International Journal of Applied Engine-ering Research. 2016. - 11 (11). - P. 7505-7508.

9. Effect of fault stress regime on the mechanical stability of horizontal boreholes / S.S.T. Moradi, M.F. Ghasemi, N.I. Nikolaev, Y.V. Lykov // GeoBaikal 2016 - 4th International Conference: From East Siberia to the Pacific - Geology, Exploration and Development. 2016. DOI: 10.3997/2214-4609.201601704
10. Geomechanical study of well stability in high-pressure, high-temperature conditions / S.S.T. Moradi, N.I. Nikolaev, I.V. Chudinova, A.S. Martel // Geomechanics and Engineering. - 2018. 16(3). - P. 331-339. DOI: 10.12989/gae.2018.16.3.331

11. Tabatabaee Moradi S.S., Nikolaev N.I. Considerations of cementing directional wells in highpressure, high-temperature conditions // 7th EAGE Saint Petersburg International Conference and Exhibition: Understanding the Harmony of the Earth's Resources Through Integration of Geosciences. - 2016. P. 11-15. DOI: 10.3997/2214-4609.201600227

12. Литвиненко В.С., Николаев Н.И. Технологические жидкости для повышения эффективности строительства и эксплуатации нефтяных и газовых скважин // Записки Горного института. - 2011. T. 194. - C. 84-90.

13. Николаев Н.И., Леушева Е.Л. Разработка составов промывочных жидкостей для повышения эффективности бурения твердых горных пород // Записки Горного института. - 2016. - Т. 219. C. 412-420. DOI: 10.18454/pmi.2016.3.412

14. Газожидкостные промывочные смеси для первичного вскрытия пластов в условиях аномально низких пластовых давлений / М.В. Турицына, А.В. Ковалев, В.А. Морозов, Г.Ю. Телеев, Е.В. Чернобровин, А.А. Щербаков // Нефтяное хозяйство. - 2012. - № 9. - С. 58-59.

15. Газожидкостные промывочные смеси для заканчивания скважин в условиях аномально низких пластовых давлений / М.В. Турицына, Е.В. Чернобровин, В.А. Морозов, Г.Ю. Телеев, А.В. Ковалев, Е.П. Рябоконь // Нефтяное хозяйство. 2012. - № 8. - C. 111-113.

16. Blinov P.A., Dvoynikov M.V. The process of hardening loose rock by Mud Filtrat // International Journal of Applied Engineering Research. - 2016. 11 (9). - P. 6630-6632.

17. Leusheva E., Morenov V. Research of clayless drilling fluid influence on the rocks destruction efficiency // International Journal of Applied Engineering Research. - 2017. - 12 (6). P. 945-949. 
18. Morenov V., Leusheva E., Martel A. Investigation of the fractional composition effect of the carbonate weighting agents on the rheology of the clayless drilling mud // International Journal of Engineering, Transactions A: Basics. - 2018. - 31(7). P. 1152-1158. DOI: 10.5829/ije.2018.31.07a.21

19. Nutskova M.V., Dvoynikov M.V., Kuchin V.N. Improving the quality of well completion in order to limit water inflows // Journal of Engineering and Applied Sciences. - 2017. - 12(22). - P. 5985-5989. DOI: $10.3923 /$ jeasci.2017.5985.5989

20. Nutskova M.V., Kupavyh K.S. Improving the quality of well completion in deposits with abnormally low formation pressure // International Journal of Applied Engineering Research. - 2016. 11 (11). - P. 7298-7300.

21. Вафин Р.М. Повышение качества вскрытия продуктивных пластов путем комплексного использования полисахаридов // Вестник Пермского национального исследовательского политехнического университета. Геология. Нефтегазовое и горное дело. - 2011. - Т. 10, № 1. - С. 47-52.

22. Курбанов Х.Н. Буровые растворы для сохранения фильтрационно-емкостных свойств коллектора при первичном вскрытии пласта // Инженер-нефтяник. - 2016. - № 3. - Р. 18-22.

23. Blinov P.A., Dvoynikov M.V. Rheological and filtration parameters of the polymer salt drilling fluids based on xanthan gum // Journal of Engineering and Applied Sciences. - 2018. - 13 (14). - P. 5661-5664. DOI: 10.3923 jeasci.2018.5661.5664

24. Blinov P.A., Podoliak A.V. The method of determining the effects of drilling fluid on the stability of loose rocks // International Journal of Applied Engineering Research. - 2016. - 11 (9). - P. 6627-6629.

25. Morenov V., Leusheva E. Development of drilling mud solution for drilling in hard rocks // International Journal of Engineering, Transactions A: Basics. - 2017. - 30(4). - P. 620-626.

26. Оптимизация процессов промывки и крепления скважин / А.Г. Аветисов, В.И. Бондарев, А.И. Булатов, Е.И. Сукуренко. - Москва: Недра, 1980. $-221 \mathrm{c}$.

27. Разработка, опыт применения и перспективы повторного использования инвертноэмульсионных буровых растворов / О.В. Гаршина, П.А. Хвощин, О.Г. Кузнецова, И.А. Кудимов, Г.В. Окромелидзе // Нефтяное хозяйство. - 2011. № 10. - С. 56-59.

28. Конесев В.Г., Хомутов А.Ю. Результаты применения растворов на углеводородной основе при вскрытии продуктивных пластов на месторождениях ОАО «Газпромнефть - Ноябрьскнефтегаз» // Нефтяное хозяйство. - 2016. - № 5. - С. 44-45.

29. Некрасова И.Л. Совершенствование критериев оценки качества буровых растворов на углеводородной основе в зависимости от горногеологических условий их применения // Вестник Пермского национального исследовательского политехнического университета. Геология. Нефтегазовое и горное дело. - 2018. - Т. 18, № 2. C. 12-139.DOI: $10.15593 / 2224-9923 / 2018.4 .3$

30. Яковлев А.А., Турицына М.В. Исследование свойств газожидкостных смесей и выбор их рациональных составов для первичного вскрытия пластов с аномально низкими давлениями // Инженернефтяник. - 2012. - № 2. - С. 27-31.

31. Яковлев А.А., Турицына М.В. Обоснование применения и исследование составов газожидкостных смесей для промывки скважин в условиях аномально низких пластовых давлений // Вестник Пермского национального исследовательского политехнического университета. Геология. Нефтегазовое и горное дело. - 2012. - Т. 11, № 4. - С. 42-48.

32. Яковлев А.А., Турицына М.В. Обоснование способа и выбор промывочного агента для первичного вскрытия пластов с аномально низким давлением // Записки Горного института. - 2013. T. 206. - C. 116-119.

33. Повышение эффективности бурения многозабойных скважин за счет применения растворов на углеводородной основе / Д.Л. Бакиров, Э.В. Бабушкин, М.М. Фаттахов, Д.В. Малютин // Нефтяное хозяйство. - 2016. - № 8. - С. 28-30.

34. Результаты испытания буровых растворов на углеводородной основе при зарезке боковых стволов на Нонг-Еганском месторождении / Д.Л. Бакиров, П.П. Подкуйко, Э.В. Бабушкин, М.М. Фаттахов, И.К. Ахметшин // Нефтяное хозяйство. -2012 . - № 11. - С. 108-109.

35. Булатов А.И., Провелков Е.Ю., Проселков Ю.М. Бурение горизонтальных скважин. Краснодар: Советская Кубань, 2008. - 424 с.

36. Исследование свойств тампонажных растворов для крепления нефтяных скважин с протяженным горизонтальным участком, пробуренных с использованием роторных управляемых систем / Е.В. Кожевников, Н.И. Николаев, А.А. Мелехин, М.С. Турбаков // Нефтяное хозяйство. - 2015. - № 9. - С. 58-60.

37. Исследование смазывающих добавок к буровым растворам для снижения коэффициента 
трения при строительстве скважин роторными управляемыми системами / А.А. Мелехин, С.Е. Чернышов, П.А. Блинов, М.В. Нуцкова // Нефтяное хозяйство. - 2016. - № 10. - С. 52-55.

38. Influence of mud filtrate on the stress distribution in the row zone of the well / P.A. Blinov, M.V. Dvoynikov, K.M. Sergeevich, A.E. Rustamovna // International Journal of Applied Engineering Research. - 2017. - 12 (15). - P. 5214-5217.

39. Агабальянц Э.Г. Промывочные жидкости для осложненных условий бурения. - Москва: Недра, 1982. $-184 \mathrm{c}$.

40. Басарыгин Ю.М., Булатов А.И., Проселков Ю.М. Осложнения и аварии при бурении нефтяных и газовых скважин: учебник. - Москва: Недра, 2000. -680 c.

41. Городнов В.Д. Буровые растворы: учебное пособие. - Москва: Недра, 1985. - 131 с.

42. Духон П.Ю., Долгих А.Е., Шерман Г.П. Методы контроля состава и свойств раствора на углеводородной основе // Труды института геологии и разработки горючих ископаемых АН СССР. - 1976. - Вып. 27.

43. Кравчук М.В. Выбор бурового раствора при вскрытии терригенных отложений на месторождениях Тимано-Печорской провинции // Строительство нефтяных и газовых скважин на суше и на море. -2015 . - № 1-2.

44. Мухин Л.К. Буровые растворы на углеводородной основе для бурения в осложненных условиях и вскрытия продуктивных пластов: диссертация на соискание ученой степени доктора технических наук. - Москва, 1971. - 300 c.
45. Экологические аспекты применения буровых растворов на углеводородной основе / Л.К. Мухин, В.Л. Заворотный, Л.А. Травникова, М.А. Ропяная, Н.И. Ефимов, Б.В. Касперский, С.Н. Шишков // Проблемы строительства нефтяных и газовых скважин: тезисы докладов к Всесоюзной конференции. - Краснодар, 1990.

46. Орлов Г.А., Кендис М.Ш., Глущенко В.Н. Применение обратных эмульсий в нефтедобыче. Москва: Недра, 1991. - 225 с.

47. Влияние химической природы эмульгаторов ряда производных жирных кислот и этаноламинов на свойства гидрофобно-эмульсионных буровых растворов / В.А. Яновский, М.О. Андропов, Р.А. Чуркин, Р.С. Фахрисламова, А.Д. Фензель, К.М. Минаев // Нефтяное хозяйство. - 2018. № 1. - С. 42-47.

48. Влияние условий синтеза эмульгатора на свойства гидрофобно-эмульсионного бурового раствора / В.А. Яновский, А.Д. Фензель, М.О. Андропов, Р.С. Фахрисламова, А.С. Захаров, Р.А. Чуркин, К.М. Минаев // Нефтяное хозяйство. - 2018. - № 6. - С. 93-97. DOI: $10.24887 / 0028-2448-2018-6-93-97$

49. Об утверждении федеральных норм и правил в области промышленной безопасности «Правила безопасности в нефтяной и газовой промышленности»: Приказ от 12 марта 2013 г. № 101 [Электронный pecypc]. - URL: http://www.ptb72.ru/upload/ Prikaz_RTN_ot_12.03.13_101.pdf (дата обращения: 16.02.2019).

Please cite this article in English as:

Nutskova M.V., Sidorov D.A., Tsikplonu D.E., Sergeev G.M., Vasiliev N.I. Studies of hydgocarbon-based muds for drilling-in productive formations. Perm Journal of Petroleum and Mining Engineering, 2019, vol.19, no.2, pp.138-149. DOI: $10.15593 / 2224-9923 / 2019.2 .4$

Просьба ссылаться на эту статью в русскоязычных источниках следующим образом:

Исследования буровых растворов на углеводородной основе для первичного вскрытия продуктивных пластов / М.В. Нуцкова, Д.А. Сидоров, Д.Э. Тсикплоу, Г.М. Сергеев, Н.И. Васильев // Вестник Пермского национального исследовательского политехнического университета. Геология. Нефтегазовое и горное дело. - 2019. - Т.19, №2. - С.138-149. DOI: $10.15593 / 2224-9923 / 2019.2 .4$ 